\title{
A definition of mountains and their bioclimatic belts for global comparisons of biodiversity data
}

\author{
Christian Körner · Jens Paulsen • Eva M. Spehn
}

Received: 9 December 2010/Revised: 8 July 2011 / Accepted: 19 July 2011 / Published online: 25 August 2011

(C) The Author(s) 2011. This article is published with open access at Springerlink.com

\begin{abstract}
This is the first quantitative attempt at a global areal definition of 'alpine' and 'montane' terrain by combining geographical information systems for topography with bioclimatic criteria (temperature) subdividing the life zones along elevational gradients. The mountain definition adopted here refrains from any truncation by low elevation thresholds, and defines the world's mountains by a common ruggedness threshold $(>200 \mathrm{~m}$ difference in elevation within a $2.5^{\prime}$ cell, $0.5^{\prime}$ resolution), arriving at $16.5 \mathrm{Mio} \mathrm{km}^{2}$ or $12.3 \%$ of all terrestrial land area outside Antartica being mountains. The model employed accounts for criteria of "mountainous terrain" for biological analysis, and thus arrives at a smaller land area fraction than hydrologically oriented approaches, and by its $2.5^{\prime}$ resolution, it includes less unstructured terrain (such as large plateaus, very wide valleys or basins) than earlier approaches. The thermal delineation of the alpine and nival biogeographic region by the climatic tree limit (the lower boundary of the alpine belt) arrives at $2.6 \%$ or $3.55 \mathrm{Mio} \mathrm{km}^{2}$ of the global land area outside Antarctica (21.5\% of all mountain terrain). Seven climate-defined life zones in mountains facilitate large-scale (global) comparisons of biodiversity information as used in the new electronic 'Mountain Biodiversity Portal' of the Global Mountain Biodiversity Assessment (GMBA).
\end{abstract}

Keywords Mountain definition · Ruggedness · Mountain life zones · Alpine - Montane . Thermal belts

C. Körner · J. Paulsen · E. M. Spehn $(\bowtie)$

Institute of Botany, University of Basel,

Schoenbeinstrasse 6, 4056 Basel, Switzerland

e-mail:gmba@unibas.ch

\section{Introduction}

Much of the Earth's terrestrial surface is covered by mountains, which host a larger proportion of the Earth's biodiversity than would be expected by area (Körner 2004, Mutke and Barthlott 2005). Due to steep environmental gradients over short distances, mountains exemplify 'natural experiments' that permit testing ecological theories and questions of adaptive evolution (Körner 2000, Körner et al. 2007).

In recent years, legacy data on species' distributions (most often hosted in museums and natural history collections) have become available in digital form. To the extent such data are geo-referenced, including precise information on elevation, they can be linked to geographical information systems on topography, climate, geology, etc. Such electronic archives offer a new way to explore biodiversity, its causes, and evolution (Körner et al. 2007, Spehn and Körner 2010). The electronic 'Mountain Biodiversity Portal' of the Global Mountain Biodiversity Assessment of DIVERSITAS (GMBA 2010) is a thematic portal for mountains with open access to biological data hosted by the Global Biodiversity Information Facility (GBIF). The user is offered a mountain relevant area-selection, with a horizontal (region) and vertical (elevation, climate) dimension, based on a coherent convention of terms. The Mountain Biodiversity Portal aims at becoming a standard tool for the world community of mountain biologists and ecologists. This article presents the conceptual framework of this biogeographical mountain convention.

\section{GMBA definition of mountains}

While seemingly obvious to most people, it is very difficult to offer a quantitative generalizable scientific definition of 
what a mountain is that can be used for mountain-specific data retrieval in biodiversity research. A mountain cannot be defined by elevation, simply because there are elevated plateaus such as the North-American short-grass Prairies at around 2,000 $\mathrm{m}$ elevation or the vast plateaus in central Asia, while steep coastal ranges may exemplify 'real' mountains near sea level. Similarly, mountains cannot be defined by climate, given that any cold category would include arctic and antarctic lowland, and tropical mountains range from equatorial rain forests to arctic life conditions near their summits.

The only common feature of mountains is their steepness (slope angle to the horizontal) which causes the forces of gravity to shape them and create habitat types and disturbances typical for mountains and which make exposure a driving factor of life (Körner 2004). Because steepness is a feature of each specific slope that cannot be quantified at a spatial scale of such a global database, the Mountain Biodiversity Portal adopts ruggedness as a simple and pragmatic proxy for steepness, to define mountains across the globe.

Ruggedness is defined here as the maximal elevational difference among neighbouring grid points. Calculations are based on the digital elevation model (DEM) used by WorldClim (Hijmans et al. 2005). Elevation of every cell in a $30^{\prime \prime}$ grid was compared with elevation of its eight neighboring cells. If the difference between the lowest and highest of these nine $30^{\prime \prime}$ grid cells exceeds $200 \mathrm{~m}$, the central cell is assigned as 'rugged' i.e. belonging to mountain terrain, as a matter of convention. We then reduced the dataset to a resolution of $2^{\prime} 30^{\prime \prime}$ (by using every 5 th $30^{\prime \prime}$ cell in latitude and longitude) for the final calculation of ruggedness, to arrive at a manageable dataset, mainly because WorldClim Climate data are on a $2^{\prime} 30^{\prime \prime}$ grid only. The Mountain Biodiversity Portal therefore operates at a $2^{\prime} 30^{\prime \prime}$ resolution of the terrestrial surface (c. $4.6 \times 4.6 \mathrm{~km}$ or $21.5 \mathrm{~km}^{2}$ at the equator and narrower at higher latitudes, i.e. cos ${ }^{\circ}$ latitude, resulting in $15.2 \mathrm{~km}^{2}$ at $45^{\circ}$, and $10.7 \mathrm{~km}^{2}$ at $60^{\circ}$ latitude).

We gave the selection of the ruggedness threshold of $200 \mathrm{~m}$ elevational difference (in 9 30" cells) a lot of thought. In a logarithmic land area versus ruggedness plot, a $200 \mathrm{~m}$ ruggedness threshold roughly marks the point at which the land area starts to decline logarithmically as ruggedness is further increased. A main criterion with regard to biodiversity was that the threshold is inclusive rather than exclusive with regard to valley floors, adjacent forelands and plateaus. The $200 \mathrm{~m}$ threshold turned out to meet this demand well (Fig. 1). As can be seen in this example for the transition of the Swiss Alps to the Swiss midlands (or Swiss plateau), the model includes all mountain valleys except the very widest (approx. $>2.5 \mathrm{~km}$ width). The patterns around Lake Brienz (the top right lake in Fig. 1) shows that mountain pixels extend substantially into flat terrain and foothills. A few hills in the otherwise even lowlands (mainly agricultural land between 300 and $500 \mathrm{~m}$ elevation) are also depicted as 'mountains'. We intentionally used a reference map with roads and cities in Fig. 1 to visualize the mountainlowland contrast. Earlier mountain definitions (such as Meybeck et al. 2001, and others, see below) would place most of that hilly lowland terrain into the mountain category, which might make sense e.g. in a hydrological context, but would seem inappropriate in a mountain biodiversity context. With this definition, 16.5 Mio $\mathrm{km}^{2}$ or $12.3 \%$ of the terrestrial surface is rugged at this scale (Table 1 offers results for 3 different ruggedness thresholds).

Ruggedness, as defined here, may refer to a single $>200 \mathrm{~m}$ elevational distance between two out of nine neighboring $30^{\prime \prime}$ grid cells on a $2^{\prime} 30^{\prime \prime}$ scale. The remainder of its area can exhibit low inclination terrain (valley floors, small plateaus, forelands), therefore this convention also covers non-rugged terrain adjacent to mountains at the given $2^{\prime} 30^{\prime \prime}$ resolution $(4.6 \times 4.6 \mathrm{~km}$ at the equator). In rare cases a pixel may not be assigned rugged, although it is, because the grid failed to capture a certain landscape feature at the $30^{\prime \prime}(0.9 \mathrm{~km})$ resolution. Needless to say that no topographic information $<30^{\prime \prime}$ is reflected in these data, hence, also the boundary of mountains adjacent to lowland is not more accurate than $30^{\prime \prime}$ (c. $0.9 \mathrm{~km}$ at the equator).

Earlier attempts to define mountains go back to the 19th century, and used several criteria such as elevation, volume, relief and steepness, but have been inconsistent on a global scale (Gerrard 1990). A recent attempt to arrive at a global mountain convention by Kapos et al. 2000 used a mixture of elevation and ruggedness criteria (elevation $>2.500 \mathrm{~m}$; or $1,500-2,499 \mathrm{~m}$ if the slope is $>2^{\circ}$; or $1,000-1,499 \mathrm{~m}$ if the slope is $5^{\circ}$ and the local elevation range at a radius of $7 \mathrm{~km}$ is $>300 \mathrm{~m}$; or 300-999 $\mathrm{m}$ if the local elevation range at a radius $7 \mathrm{~km}$ is $>300 \mathrm{~m}$ ). Meybeck et al. 2001 used basically the same approach and resolution as we did, defining mountains with a fixed relief roughness at a resolution of $30^{\prime} \times 30^{\prime}(\mathrm{RR}=$ maximum minus minimum elevation per cell divided by half the cell width). The main difference is that Meybeck et al. 2001 used a cut off towards the lower end of $500 \mathrm{~m}$ elevation and used an even lower ruggedness threshold $(40 \%)$, whereas we use ruggedness with a single, higher threshold $(200 \mathrm{~m}$ or $77 \%$ ) only, independent of meters of elevation. Both these earlier definitions that used a cut-off elevation (300 or $500 \mathrm{~m}$ ) had been selected for hydrological (Meybeck et al. 2001) or mountain forest questions (Kapos et al. 2000). For mountain biodiversity, it seems to be appropriate to restrict forelands and valleys to $<2 \mathrm{~km}$ distance to mountains thus including the immediate forelands or plateaus to that extent only.

By including less structured terrain, both earlier definitions arrived at a larger extent of mountain terrain (20.9\% of total land area in Meybeck et al. 2001 at their $>40 \mathrm{~m} \mathrm{~km}^{-1}$ category), and 24\% in Kapos et al. 2000. As discussed by 


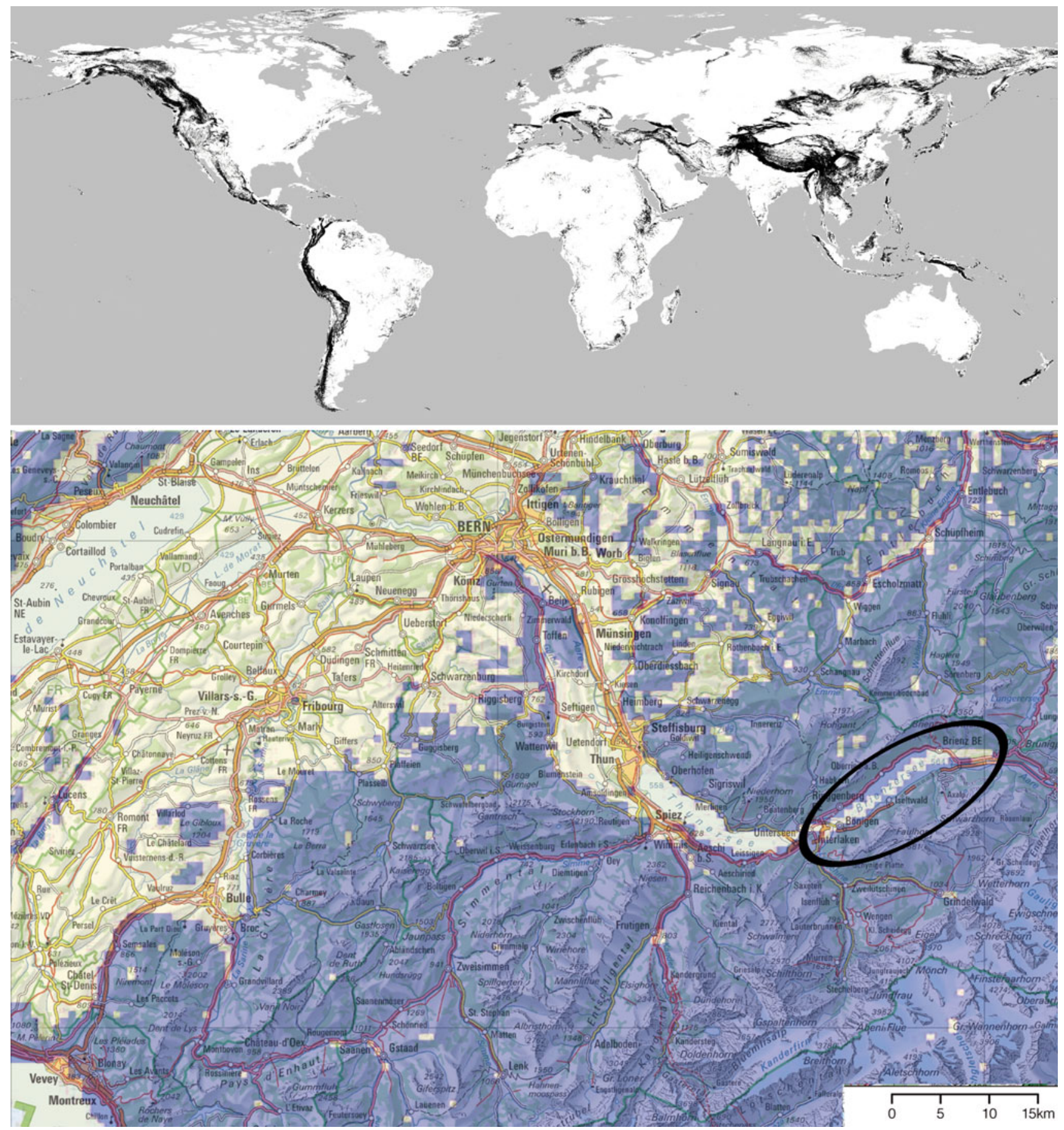

Fig. 1 Top Mountain area according to our ruggedness definition (elevational distance $>200 \mathrm{~m}$ between nine $30^{\prime \prime}$ pixels) on the global scale (black, non-rugged terrain in white). Below Mountain area on the regional scale (blue, non-rugged terrain in yellow). The below map shows a part of Switzerland from Neuchatel to Grindelwald

Meybeck et al. 2001, the larger area of Kapos et al. 2000 is most likely due to the extensive inclusion of high plateaus such as the Tibetan Plateau, and a coarser scale and thus greater tolerance of including forelands and basins (Kapos et al. 2000). Meybeck et al. 2001 adapted a 'degree of
(6.78075 E, 47.03915 N, 8.21894 W, 46.40867 S). Note the encircled area for lake Brienz illustrating the extent of flat mountain foreland terrain included in our mountain definition. All mountain valleys except small parts of the very widest valleys are covered by our mountain definition. Topographic map by [http://map.geo.admin.ch]

dissectedness' of $40-80 \mathrm{~m} \mathrm{~km}^{-1}$ (40-80\%) as moderately dissected terrain that may be seen as separating hills from mountains. Our $200 \mathrm{~m}$ ruggedness threshold corresponds to $77 \%$ degree of dissectedness of Meybeck et al. 2001. As our analysis (Table 1) shows, a ruggedness of only $50 \mathrm{~m}$ instead 
Table 1 Terrestrial land area outside Antarctica (a total of $134.6 \mathrm{Mio} \mathrm{km}^{2}$ ) subdivided by different thresholds of ruggedness (R) expressed as maximum contrast in elevation among 9 pixels of $30^{\prime \prime}$ in each cell of a $2^{\prime} 30^{\prime \prime}$ geographical grid

\begin{tabular}{|c|c|c|c|c|c|c|c|c|c|c|}
\hline \multirow[t]{2}{*}{$\mathrm{R}$ (meters of elevation) } & \multicolumn{10}{|c|}{ Continent/region $\left(\right.$ Mio $\mathrm{km}^{2}$ ) } \\
\hline & As & $\mathrm{Eu}$ & Af & $\mathrm{N}-\mathrm{A}$ & S-A & Gld & Aus & Oce & Total & $\%$ \\
\hline All & 44.6 & 9.8 & 30.0 & 22.1 & 17.8 & 2.1 & 7.7 & 0.5 & 134.6 & 100.0 \\
\hline$<50$ & 23.5 & 6.7 & 23.5 & 14.0 & 11.8 & 1.8 & 6.8 & 0.1 & 88.2 & 65.5 \\
\hline$\geq 50<200$ & 12.2 & 2.2 & 5.3 & 5.2 & 3.8 & 0.2 & 0.8 & 0.2 & 9.9 & 22.2 \\
\hline$\geq 200$ & 8.9 & 0.9 & 1.2 & 2.9 & 2.2 & 0.1 & 0.1 & 0.2 & 16.5 & 12.3 \\
\hline
\end{tabular}

As Asia, Ee Europe, Af Africa, $N$-A North America, $S$-A South America, Gld greenland, Aus Australia and New Zealand, Oce Oceania (including the large islands of SE Asia)

of our $200 \mathrm{~m}$ threshold (i.e. a single elevational contrast of $50 \mathrm{~m}$ in a $4.6 \times 4.6 \mathrm{~km}$ area near the equator; equal to ca. $10-20 \mathrm{~m} \mathrm{~km}^{-1}$ in Meybeck et al. 2001 attributed by them as nearly flat) almost doubles the mountain area.

\section{Seven thermal belts}

For a global comparison of mountain biota it is essential that the latitudinal change in life conditions with elevation is accounted for. Hence, elevational belts have to be converted into climatic belts that account for the rise of isotherms as one approaches the equator. Here we suggest subdividing mountains vertically into seven thermal life zones (thermal belts) defined by temperature only and, thus, accounting for the latitudinal change in elevation of thermally similar areas. All belts refer to the best defined biome boundary in mountains, the high elevation climatic treeline, separating the treeless alpine and the potentially forested montane belts. From there, one can go up (alpine and nival) or down (montane and lower) based on temperature criteria (Table 2). Thermal belts are defined by a model using WorldClim climate data (daily air temperatures and snow cover) and field data from across the globe that characterize the position of the potential high elevation climatic treeline, irrespective of the actual presence or absence of trees in a given area (Körner and Paulsen 2004 and additional data)
High elevation treeline

The Mountain Biodiversity Portal adopts the position of the potential, climatic high elevation treeline as the main reference line for life zones in mountains. Defined by an isotherm, it exerts an ideal bioclimatic reference line for any comparison of mountain biota worldwide (Körner 2007). The treeline may be located at a few hundred meters above sea level near the arctic circle, but may reach $>4,000 \mathrm{~m}$ in the tropics and subtropics (as long as annual precipitation is $>250 \mathrm{~mm}$ ). The climatic treeline marks the limit of tall upright life forms that are aerodynamically strongly coupled to the free atmosphere and, thus, are facing thermal constraints well represented by weather station data (Körner 2007). In contrast, low stature shrub- or grass-type vegetation at least periodically decouples aerodynamically from ambient conditions and experiences/produces peculiar microclimates, substantially warmer than what climate stations would report (Scherrer and Körner 2010). The transition from potentially forested to treeless terrain is co-defined by an empirically determined minimum duration of the growing season of 94 days and a mean growing season temperature of $6.4^{\circ} \mathrm{C}$. Where trees or any other vegetation is naturally absent e.g. due to lack of moisture, this line is still used as an isotherm that separates terrain above and below (hence, there may be alpine deserts and montane deserts). The
Table 2 The global area of bioclimatic mountain belts for rugged terrain

Temperatures refer to growing season (GS) mean temperatures (for definition see text). $M$, percentage of total mountain area $\left(100 \%=16.5 \mathrm{Mio} \mathrm{km}^{2}\right)$, $G$, percentage of total terrestrial area outside Antarctica $\left(100 \%=134.6 \mathrm{Mio} \mathrm{km}^{2}\right)$

\begin{tabular}{lcrr}
\hline Thermal belts & Area $\left(\right.$ Mio $\left.\mathrm{km}^{2}\right)$ & $\mathrm{M}(\%)$ & $\mathrm{G}(\%)$ \\
\hline 1. Nival $\left(<3.5^{\circ} \mathrm{C}, \mathrm{GS}<10\right.$ days $)$ & 0.53 & 3.24 & 0.40 \\
2. Upper alpine $\left(<3.5^{\circ} \mathrm{C}, \mathrm{GS}>10\right.$ days $<54$ days $)$ & 0.75 & 4.53 & 0.56 \\
3. Lower alpine $<6.4^{\circ} \mathrm{C}, \mathrm{GS}<94$ days $)$ & 2.27 & 13.74 & 1.68 \\
The treeline & & & \\
4. Upper montane $\left(>6.4 \leq 10^{\circ} \mathrm{C}\right)$ & 3.39 & 20.53 & 2.51 \\
5. Lower montane $\left(>10 \leq 15^{\circ} \mathrm{C}\right)$ & 3.74 & 22.64 & 2.78 \\
6. Remaining mountain area with frost $\left(>15^{\circ} \mathrm{C}\right)$ & 1.34 & 8.11 & 0.99 \\
7. Remaining mountain area without frost $\left(>15^{\circ} \mathrm{C}\right)$ & 4.49 & 27.22 & 3.34 \\
Total & 16.51 & 100.00 & 12.26 \\
\hline
\end{tabular}


growing season is defined from smoothed perennial time series in WorldClim by the first transition of the daily mean of air temperatures per $2.5^{\prime}$ grid through $0.9^{\circ} \mathrm{C}$, and its fall below $0.9^{\circ} \mathrm{C}$ at the end. These numbers have been obtained from iterative searches for best parameterization of the model across several hundred reference points across the globe, improving the criteria as originally presented by Körner and Paulsen 2004.

\section{Additional isotherms}

Below the treeline isotherm, season length may be anywhere between 95 and 365 days. A further critical, biologically relevant threshold is the occurrence of freezing. Hence the lowest mountain belt is defined by the complete absence of freezing (the 'banana' belt). Since WorldClim does not offer absolute minima of temperature at hourly resolution,
Fig. 2 Mountain land area $\left(\right.$ Mio $\mathrm{km}^{2}$ ) for each thermal belt across all latitudes. Note the Northern versus Southern Hemisphere asymmetry of mountain land area. About one third of all mountain terrain is presumably frost free (orange)

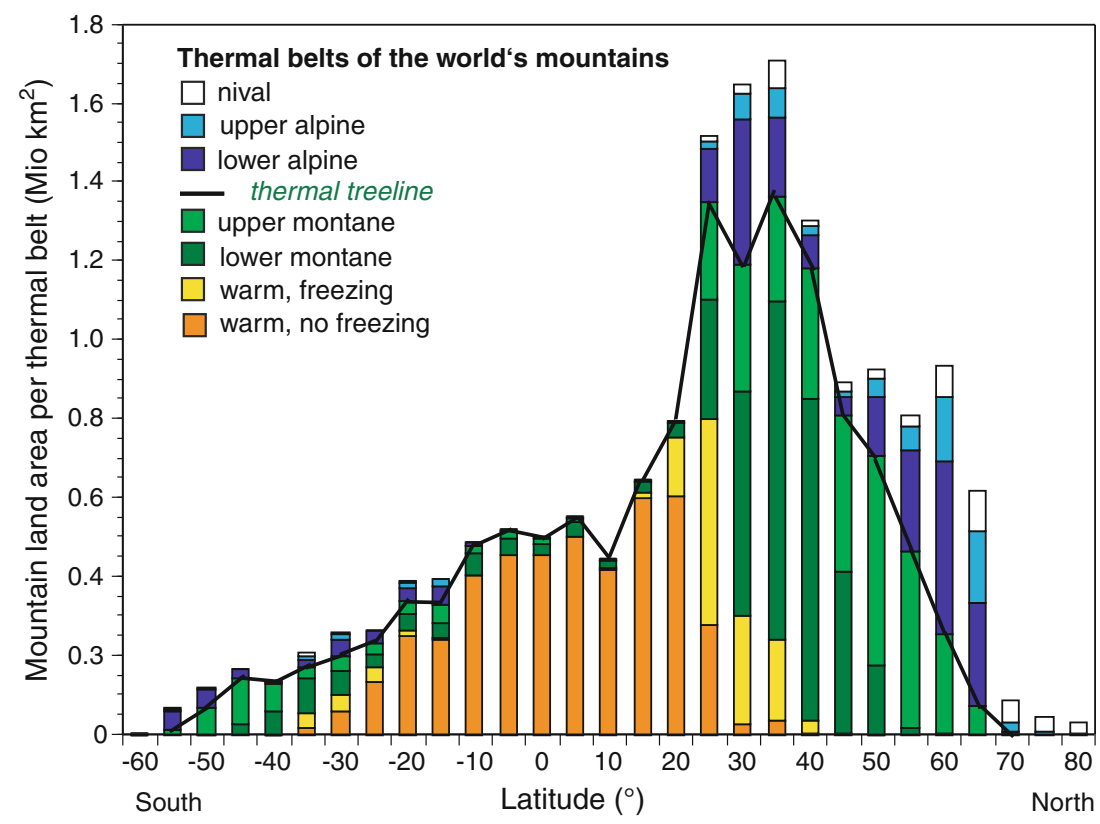

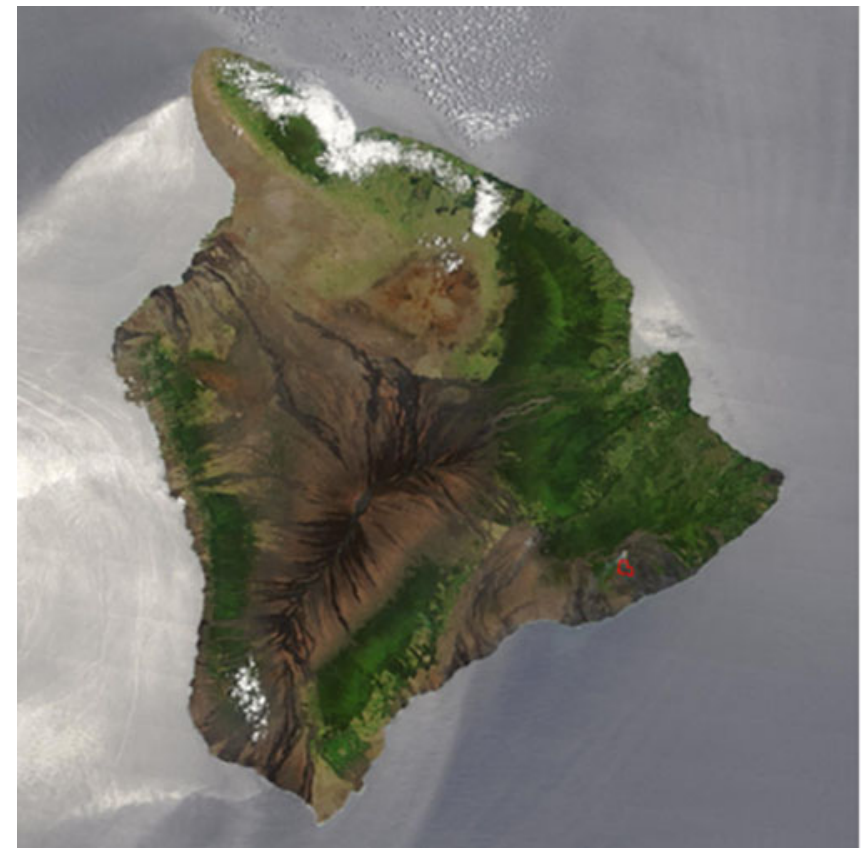

Fig. 3 Thermal belts of Hawaii' Big Island $\left(19.583333^{\circ},-155.5^{\circ}\right)$ mountains (Mauna Kea, 4205 m a.s.l in the north, Mauna Loa 4169 m a.s.l in the south). See Fig. 2 for colour codes of thermal belts. Satellite

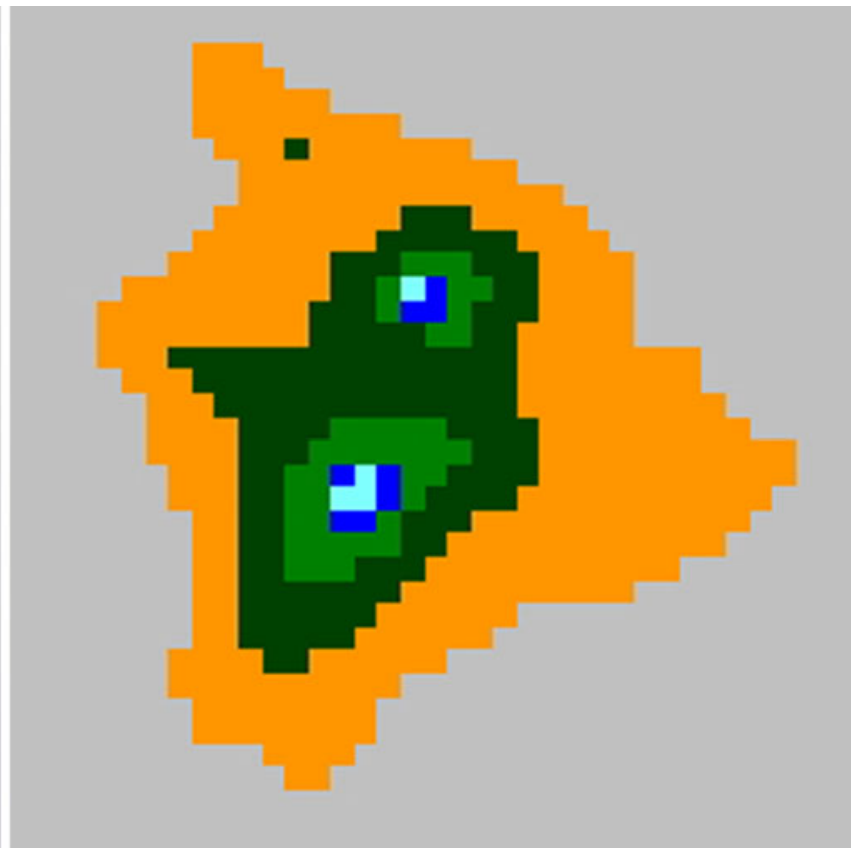

picture by Jacques Descloitres [http://commons.wikimedia.org/ wiki/File:Hawaje.jpg] 
absence of freezing was assumed, when the lowest daily mean temperature was $>5^{\circ} \mathrm{C}$. This assumption is likely to underestimate the likelihood of climatic extreme events that may be biologically decisive in open terrain. Hence the completely freezing-free area is possibly smaller than assumed here. The thermal belts as defined here cover all possible moisture regimes from permanently humid to arid and are thus, not specific to a certain type of vegetation. Therefore, these thermal belts make the mountains of the world comparable across latitudes, irrespective of their elevation in meters and moisture regimes (Table 2). With the model parameters as defined above, season length and season mean temperature were calculated for all WORLDCLIM cells (on a $2^{\prime} 30^{\prime \prime}$ grid), allowing to assign each cell to one of our thermal belt classes (Table 2). The total area of each belt was then calculated as the number of grid cells multiplied by the cell area. (Figs. 2,3)

A note of caution: working with gridded data, the accuracy of an analysis usually increases with the number of grid cells included, depending spatial resolution and extent of the phenomenon being mapped. Hence, best results are obtained for large areas (e.g. Alps, Pyrenees, Cascades, Hindu-Kush Himalaya, etc.) across which local statistical deviations from reality of both topography criteria (ruggedness) and climate data become less significant. A single grid cell may deviate from the nearest grid cell by kilometers of elevation in the case of steep mountain flanks. Further, the map is a Mercator projection and, thus, the spatial size of grid cells depends on latitude.

In summary, using these definitions, the global land area above the treeline isotherm comprises $3.55 \mathrm{Mio} \mathrm{km}^{2}$ or $21.51 \%$ of all mountain terrain (or $2.64 \%$ of all land outside Antarctica). Twenty seven percent of all mountain terrain falls in the warm, low elevation category. This surprisingly large rugged area represents the lower slopes and foothills of warm temperate, subtropical and tropical mountains.

We advise against the use of elevation in meters when defining a lower and an upper limit of biota across larger areas. Even in regional studies, there is a risk of climatic bias, because, for instance, front ranges and central ranges may differ dramatically in climate. Since life in mountains is not driven by elevation per se, but by the climatic conditions associated with elevation, thermal belts of life offer a simple, temperature-only driven zonation of mountains.

This mountain convention offers a means for consistent comparison of mountain life zones at global scales, and we hope that a large body of scientific works will emerge from the Mountain Biodiversity Portal.
Acknowledgments We thank Falk Huettmann for comments on an earlier draft of the manuscript, and three reviewers for their constructive comments. The Mountain Biodiversity Portal (http://www. mountainbiodiversity.org) is a project by the Global Mountain Biodiversity Assessment (GMBA, Basel, Switzerland) of DIVERSITAS (Paris), in cooperation with the Global Biodiversity Information Facility (GBIF, Copenhagen, Denmark) and is funded by the Swiss National Science Foundation (31FI3A-118167 to Ch. Körner).

Open Access This article is distributed under the terms of the Creative Commons Attribution Noncommercial License which permits any noncommercial use, distribution, and reproduction in any medium, provided the original author(s) and source are credited.

\section{References}

Gerrard J (1990) Mountain environments: an examination of the physical geography of mountains. Belhaven Press, London

GMBA (2010) The digital 'Mountain Biodiversity Portal'. http://www.mountainbiodiversity.org

Hijmans RJ, Cameron SE, Parra JL, Jones PG, Jarvis A (2005) Very high resolution interpolated climate surfaces for global land areas. Int J Climatol 25:1965-1978

Kapos V, Rhind J, Edwards M, Price MF, Ravilious C (2000) Developing a map of the world's mountain forests. In: Price MF, Butt $\mathrm{N}$ (eds) Forests in sustainable mountain development (IUFRO Research Series 5). CABI Publishing, Wallingford Oxon, pp 4-9

Körner Ch (2000) Why are there global gradients in species richness? Mountains may hold the answer. TREE 15:513

Körner Ch (2004) Mountain biodiversity, its causes and function. Ambio Special Rep 13:11-17

Körner Ch (2007) Climatic treelines: conventions, global patterns, causes. Erdkunde 61:316-324

Körner Ch, Paulsen J (2004) A world-wide study of high altitude treeline temperatures. J Biogeogr 31:713-732

Körner Ch, Donoghue M, Fabbro T, Häuser C, Nogués-Bravo D, Arroyo MTK, Soberon J, Speers L, Spehn E, Sun H, Tribsch A, Tykarski P, Zbinden N (2007) Creative use of mountain biodiversity databases: The Kazbegi research agenda of GMBA-DIVERSITAS. Mt Res Dev 27:276-281

Meybeck M, Green P, Vörösmarty CJ (2001) A new typology for mountains and other relief classes: An application to global continental water resources and population distribution. Mt Res Dev 21:34-45

Mutke J, Barthlott W (2005) Patterns of vascular plant diversity at continental to global scales. Biologiske Skrifter 55:521-531

Scherrer D, Körner Ch (2010) Infra-red thermometry of alpine landscapes challenges climatic warming projections. Glob Change Biol 16:2602-2613

Spehn EM, Körner Ch (2010) Data mining for global trends in mountain biodiversity. CRC Press, Taylor and Francis Group, Boca Raton 